\title{
On the Behavior of Long-lasting Cellular Echoes
}

\author{
By Takao Takeda and Hiroo Imai \\ Water Research Institute, Nagoya University, Nagoya \\ (Manuscript received 4 June 1976, in revised form 9 October, 1976)
}

\begin{abstract}
Behaviors of two long-lasting cellular echoes, which were found out among several tens of cellular echoes near Owase Meteorological Station on the 14th of September in 1972, are analysed in detail using photographs of PPI radar echoes taken every 3 minutes. Both echoes landed at the nearly same point with the speed of travelling which became slower and slower with approaching the land.

It is found out that long-lasting echo formed in a cluster of cellular echoes which had appeared over the sea about $100 \mathrm{~km}$ east-south-eastward from Owase. Though new echoes had a tendency to form in the back region of old echoes in initial stage of the cluster, they appeared in the fore region of echoes existing previously after the formation of the longlasting echo. On the basis of the results of analyses the mechanism of formation of organized precipitating convective clouds will be discussed.
\end{abstract}

\section{Introduction}

The relations between the size of radar echoes and their behavior have been studied by some authors. Newton and Fankhauser (1964) pointed out that the movements of large echoes are different in their speed and direction from those of small ones. It was found out by Battan (1953) that the life time of an isolated convective echo, which is smaller than $13 \mathrm{~km}$ in diameter, is proportional to its size and the average life time is about $23 \mathrm{~min}$. The proportionality is verified for echoes smaller than $30 \mathrm{~km}$ in diameter, which compose a hook echo, by Akiyama and Matsumoto (1970). Suzuki and Saito (1974) showed that the regression coefficients of the relation between the life time and diameter of echoes, including echoes of $70 \mathrm{~km}$ in diameter, vary under different meteorological conditions.

On the 14th of September in 1972, two echoes having life time much longer than other echoes were found out near Owase Meteorological Station among several tens of cellular echoes which formed during the period of 6 hours, though they were not different in their size and direction of movement from other echoes and synoptic features in the atmosphere were common for all echoes. The appearance of long-lasting cellular echoes implies the formation of convective systems in which the production of precipitation particles as well as air circulation are organized.

It has been shown that the circulation in some large severe storms remains nearly steady for several hours in prevailing vertical wind shear and that such storms are dominated by a single supercell (Browning, 1964: Browning and Ludlam, 1962). The general character of the air circulation was given by Newton (1950) and Browning and Ludlam (1962), and it was refined by Fankhauser (1971) including three-dimensional circulation. Its most important features are that an updraft and a downdraft were found downshear and upshear respectively and the updraft leaned in an upshear sense. This arrangement of the airflow in a convective system is very favourable for the efficient production of kinetic energy and for the prolonged maintenance of the system.

So far it has not been made clear satisfactorily what conditions are required for the formation of the organized circulation mentioned above. Takeda (1972) stated in his two-dimensional numerical simulation of a precipitating convective cloud that when the vertical wind shear changes direction at a certain level, the patterns of updraft and of rainwater content are inclined in the direction of the lower levels shear and the cloud can reach a steady state, and so it can become long-lasting with the circulation mentioned above. However, it could not be accounted for by this result of numerical simulation that only a few convective 
clouds become long-lasting among several tens of clouds. In this paper the behaviors of long-lasting cellular echoes and echoes surrounding them are studied in detail and the mechanism of formation of organized precipitating convective clouds is discussed on the basis of the results of analyses.

\section{Brief description of radar echo patterns}

Analyses are made mainly using photographs of PPI radar echoes which were taken with the interval of about 3 minutes at Nagoya Meteorological Observatory. Wave length of the radar is $5.7 \mathrm{~cm}$.

Fig. 1 shows the patterns of radar echoes obtained at gain levels of 2,4 and 6 , which correspond to 4,16 and $64 \mathrm{~mm} / \mathrm{hr}$ in rainfall intensity roughly, respectively (hereafter the echo detected at the gain level $j$ will be called $L_{j}$ echo, where $j$ is 2, 4 or 6). Many cellular $L_{4}$ echoes are scattered in large $L_{2}$ echoes during the period of 13.00 to 19.00. Most of them formed over the sea. There are some cellular $L_{6}$ echoes. The $L_{6}$ echo which is found out near Owase Meteorological Station at 17.05 and which is over the sea at 15.04 and 16.06 is one of "long-lasting" cellular echoes to be discussed in this paper. The height of its echo top is $8.5 \mathrm{~km}$ at 17.05 .

The directions of travelling of echoes determined by tracing them in photographs which were taken every $3 \mathrm{~min}$ are either from SSW to NNE or from ESE to WNW. Echoes moving with
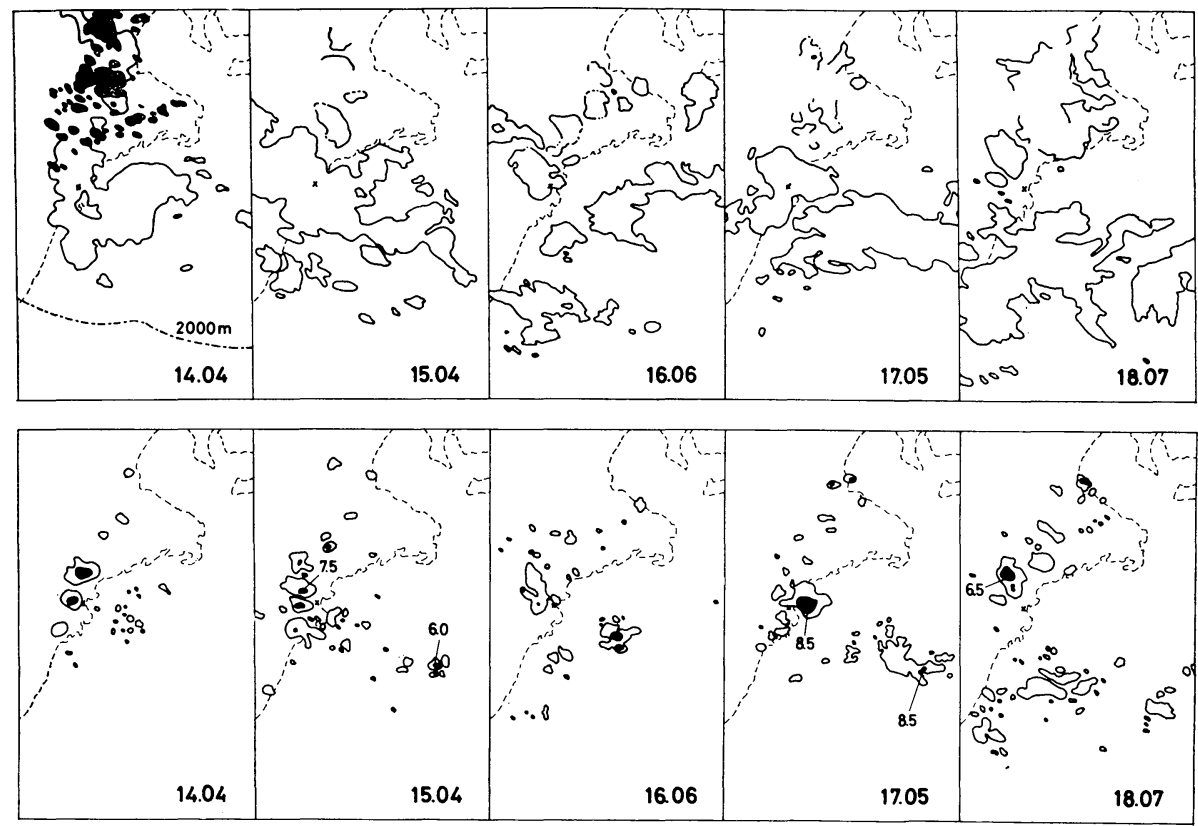

Fig. 1 Patterns of radar echoes obtained at gain levels of 2 (upper part), 4 and 6 (lower part) around the south-eastern part of Kii Peninsula on the 14th of Sept. in 1972. In the first figure of upper part ground echoes (black areas), contour of radar shadow (chain line) and Owase Meteorological Station ( $X$ sign) are shown. (Refer to Fig. 4 for scale.)

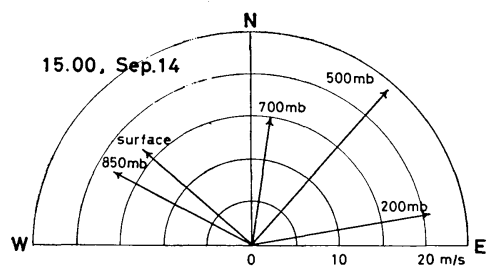

Fig. 2 Upper winds observed at Shionomisaki Meteorological Station. other direction are not seen during the period. Most of echoes larger than several tens $\mathrm{km}$ in diameter have a tendency to move to NNE and intensive cellular echoes which can be detected at gain levels higher than 4 have the direction of ESE to WNW.

As seen from upper air sounding at 15.00 LST at Shionomisaki Meteorological Station which is about $80 \mathrm{~km}$ south-south-westward from Owase Station, the directions of SSW to NNE and ESE to WNW are in good agreement with those of 
winds at levels of $500 \mathrm{mb}$ and $850 \mathrm{mb}$, respectively (Fig. 2). It can be seen in PPI radar patterns that even if two echoes which have moved with different directions meet, they continue to travel keeping their own directions after then. It would be suggested that there are two types of rainclouds during the period of 13.00 to 19.00 -clouds of type I have large horizontal size and they exist at middle levels of the troposphere, and clouds of type II are observed as cellular echoes moving to WNW. Precipitation particles from the former clouds reach the level scanned by PPI radar beam.

The behavior of large $L_{2}$ echoes is depicted in time-space cross sections of Fig. 3 which are made roughly along the direction of SSW to NNE. Striped areas in Fig. 3 indicate the existence of $L_{2}$ echo at each time in a strip of region named $a, b$ or $c$, in Fig. 4. In order to study only the movements of large echoes, the echoes of the diameter less than $5 \mathrm{~km}$ are not plotted in the cross section. It is to be noted that the travelling of large echoes to NNE is more remarkable in the region $c$ located over the sea than in the region $a$ along the seashore. In the region $a$ the formation of rainclouds due to orographic effect, specially near Owase, seems to mask the behavior of echoes associated with travelling disturbance at middle levels. The speed of travelling of large echoes tends to become faster with time. It is about $40 \mathrm{~km} / \mathrm{hr}$ at 15.00 and $60 \mathrm{~km} / \mathrm{hr}$ at 17.00 . It is
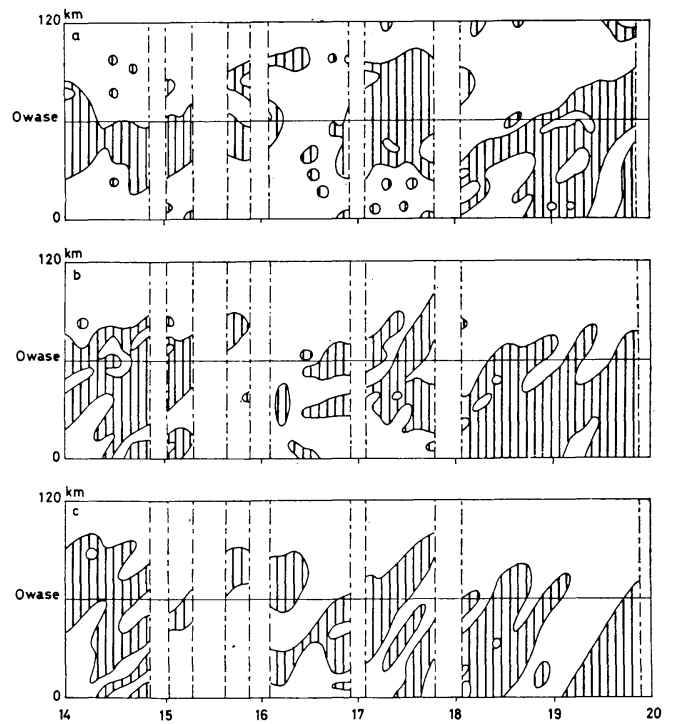

Fig. 3 Time-space cross sections of large $L_{2}$ echoes made along the direction of SSW to NNE. Figure $a, b$ or $c$ is cross section made in a strip of region named $a, b$ or $c$ in Fig. 4 . interesting that the echoes disappear near the northern edge of the region in any cross section.

Fig. 5 indicates the trajectories of $L_{4}$ and $L_{6}$ cellular echoes which travelled to WNW during the period of 13.00 to 19.00 . The length of the trajectory would be proportional to the life time of the echo approximately. We can find out two trajectories much longer than other ones. These echoes are named $M_{1}$ and $M_{2}$ as shown in Fig. 5. We could not estimate exactly how long the trajectory of $M_{1}$ is in the part shown by dots because there were no radar data in early stage of its development. PPI radar patterns indicate that the echoes with long trajectories have the horizontal size of 10 to $20 \mathrm{~km}$ in diameter as detected at gain level 4.

The relationships between the duration time of $L_{4}$ cellular echoes smaller than $20 \mathrm{~km}$ in diameter, not including $M_{1}$ and $M_{2}$, and their horizontal size are shown in Table 1. All of duration times are shorter than $42 \mathrm{~min}$ and the averaged value is about $20 \mathrm{~min}$. Table 2 is the relationships for

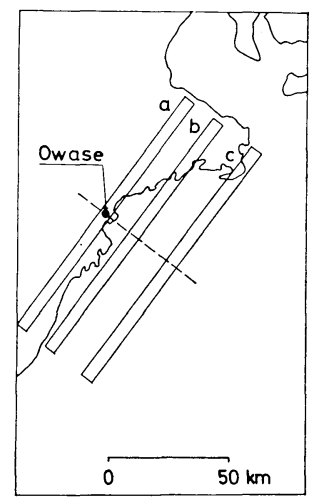

Fig. 4 Strip-like regions of $5 \mathrm{~km}$ in width which are used for time-space cross sections of Fig. 3.

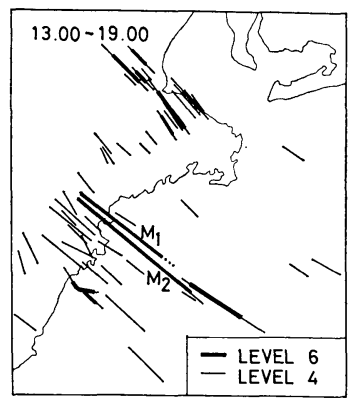

Fig. 5 Trajectories of $L_{4}$ and $L_{6}$ cellular echoes which travelled to WNW. 
Table 1. Relationships between the duration time of $L_{4}$ cellular echoes found out during the period of 13.00 to 19.00 and their horizontal size, not including $M_{1}$ and $M_{2}$ echoes. A figure in each box means the number of cellular echoes.

\begin{tabular}{|r|c|c|c|c|c|c|c|c|c|c|}
\hline min Km $^{\prime}$ & $0-2$ & $2-4$ & $4-6$ & $6-8$ & $8-10$ & $10-12$ & $12-14$ & $14-16$ & $16-18$ & $18-20$ \\
\hline $0-6$ & 1 & 8 & 7 & 3 & 1 & & & & & \\
\hline $6-12$ & 6 & 31 & 48 & 41 & 10 & 12 & 3 & 2 & & \\
\hline $12-18$ & & 2 & 8 & 11 & 10 & 9 & 3 & & & \\
\hline $18-24$ & & & & & 1 & 2 & & 1 & & \\
\hline $24-30$ & & & & & 2 & & & 1 & 1 & \\
\hline $30-36$ & & & & & & & 1 & & & \\
\hline $36-42$ & & & & & & & 1 & 1 & & \\
\hline $42-48$ & & & & & & & & & & \\
\hline $48-54$ & & & & & & & & & & \\
\hline $54-60$ & & & & & & & & & & \\
\hline
\end{tabular}

Table 2. Same as Table 1 except for $L_{2}$ echoes.

\begin{tabular}{|r|c|c|c|c|c|c|c|c|c|c|}
\hline $\min _{\mathrm{Km}}^{\mathrm{km}}$ & $0-2$ & $2-4$ & $4-6$ & $6-8$ & $8-10$ & $10-12$ & $12-14$ & $14-16$ & $16-18$ & $18-20$ \\
\hline $0-6$ & 1 & 6 & 2 & 1 & & 1 & & & & \\
\hline $6-12$ & & 20 & 32 & 26 & 7 & 6 & 1 & 2 & 1 & \\
\hline $12-18$ & & 2 & 6 & 6 & 2 & & 2 & 1 & & \\
\hline $18-24$ & & & 2 & 2 & 2 & 2 & 1 & & & \\
\hline $24-30$ & & & & & 2 & 2 & & 1 & 1 & \\
\hline $30-36$ & & & & & & & & & & \\
\hline $36-42$ & & & & & & & 1 & 1 & & \\
\hline $42-48$ & & & & & & & & & & \\
\hline $48-54$ & & & & & & & & & & \\
\hline $54-60$ & & & & & & & & & & \\
\hline
\end{tabular}

$L_{2}$ cellular echoes which do not contain $L_{4}$ echoes within them. We could not find out $L_{2}$ echoes which have the duration time longer than $42 \mathrm{~min}$. In comparison with these echoes, $M_{1}$ and $M_{2}$ echoes have remarkably long duration time. Though, as stated before, $M_{1}$ echo was unable to be traced completely owing to the lack of data, it can be identified at gain level 4 for more than $60 \mathrm{~min} . M_{2}$ echo was traced for at least $90 \mathrm{~min}$ at gain level 4. $M_{1}$ and $M_{2}$ echoes are extraordinarily long-lasting. It is interesting that both $M_{1}$ and $M_{2}$ echoes landed at the nearly same point which is very near Owase Station. It became difficult to identify them at about $15 \mathrm{~km}$ after landing on account of considerable deformation.

\section{Behavior of long-lasting echoes}

The time variations in the location and shape of $M_{1}$ and $M_{2}$ long-lasting echoes are shown in Fig. 6. $M_{2}$ echo begins to appear as a $L_{4}$ echo
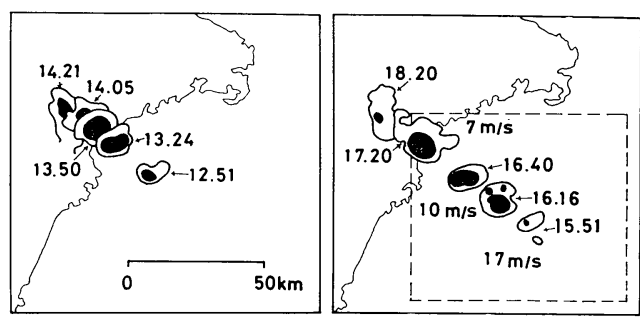

Fig. 6 Time variations in the location and shape of $M_{1}$ (left figure) and $M_{2}$ (right) long-lasting echoes as observed at gain levels of 4 and 6 .

about $50 \mathrm{~km}$ east-south-eastward from Owase Station at 15.51 and it reached seashore in one and half an hour. It is to be noted that the speed of travelling becomes slower and slower with approaching the land, though the direction remains ESE to WNW. It is $17 \mathrm{~m} / \mathrm{s}$ at 15.51 and $7 \mathrm{~m} / \mathrm{s}$ at 17.20. The horizontal size of $L_{6}$ echo hardly changes with time for about one hour. $M_{1}$ echo also has a similar behavior to $M_{2}$ echo for the changes in its size and its speed of travelling with approaching the land, though we have no data on its behavior before 12.51 .

Both echoes landed at nearly the same point. Rainfalls recorded from 13.10 to 14.00 and from 17.00 to 18.00 at Owase Station (see Fig. 7) are

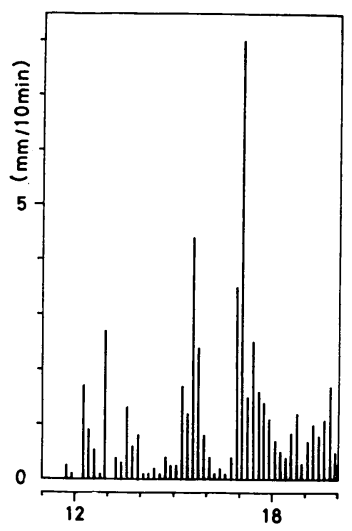

Fig. 710 min rainfall amount at Owase Station.

caused mainly in association with the passage of $M_{1}$ and $M_{2}$ echoes, respectively. In the case of $M_{2}$ echo the maximum $10 \mathrm{~min}$ rainfall amount is $8 \mathrm{~mm}$ from 17.00 to 17.10 . Both echoes tend to dissipate or to be modified in a short time after landing.

Hereafter we will study specially the behavior of $M_{2}$ echo. We have to note that $M_{2}$ echo did not develop as an isolated one in its initial stage, 

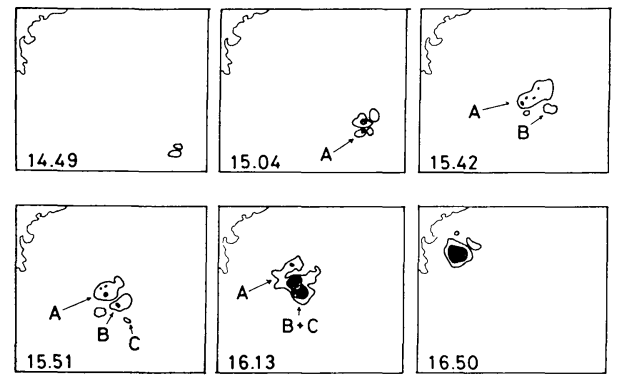

Fig. 8 Time variation of $L_{4}$ and $L_{6}$ echo patterns associated with the formation of $M_{2}$ long-lasting echo in the region shown by a dashed line in Fig. 6.

but it grew to a long-lasting one in a cluster of cellular echoes which traveled to WNW as a whole and which met at nearly right angles with large $L_{2}$ echo mentioned before. This process is shown in detail in Figs. 8 and 9. The horizontal size of the cluster is less than $20 \mathrm{~km}$ in diameter as observed at gain level 4 . The $L_{2}$ cluster appears over the sea about $100 \mathrm{~km}$ east-south-eastward from Owase Station at 14.29. $L_{4}$ echoes begin to be detected in the cluster at 14.49 .

It is interesting that new echoes tend to appear in the rear part of the cluster, in other words, a new echo forms behind a previous one. For example, we can see B echo of $L_{4}$ in the rear of A echo at 15.42 and $C$ echo of $L_{4}$ in the rear of $\mathrm{B}$ echo at 15.51. $M_{2}$ long-lasting echo seems to develop with $\mathrm{C}$ echo as its main part.

As stated before, the direction of travelling of $M_{2}$ echo is in good agreement with that of the wind at $850 \mathrm{mb}$ level. Though the speed of $17 \mathrm{~m} / \mathrm{s}$ at 15.51 is nearly the same as the wind at $850 \mathrm{mb}$, the echo has slower speed with approaching the land, keeping the direction constant. The height of $M_{2}$ echo top is estimated to be $8500 \mathrm{~m}$, which corresponds to about $300 \mathrm{mb}$ level, near Owase. The echo can be said to show the movement of direction and speed considerably different from the wind averaged through cloud layer.

The distribution of cellular echoes in the cluster and the appearance of new echoes in it are shown with the interval of about $3 \mathrm{~min}$ in more detail in Fig. 9. Echo with a letter $\mathrm{N}$ means new one. Before 16.16 new echoes have a tendency to form in the back region of echoes existing previously. After that time, however, their formation is seen in the fore region of old echoes and we could not find out any new echoes behind old ones. It is to be noted that a $L_{4}$ echo containing $L_{6}$ echo, which

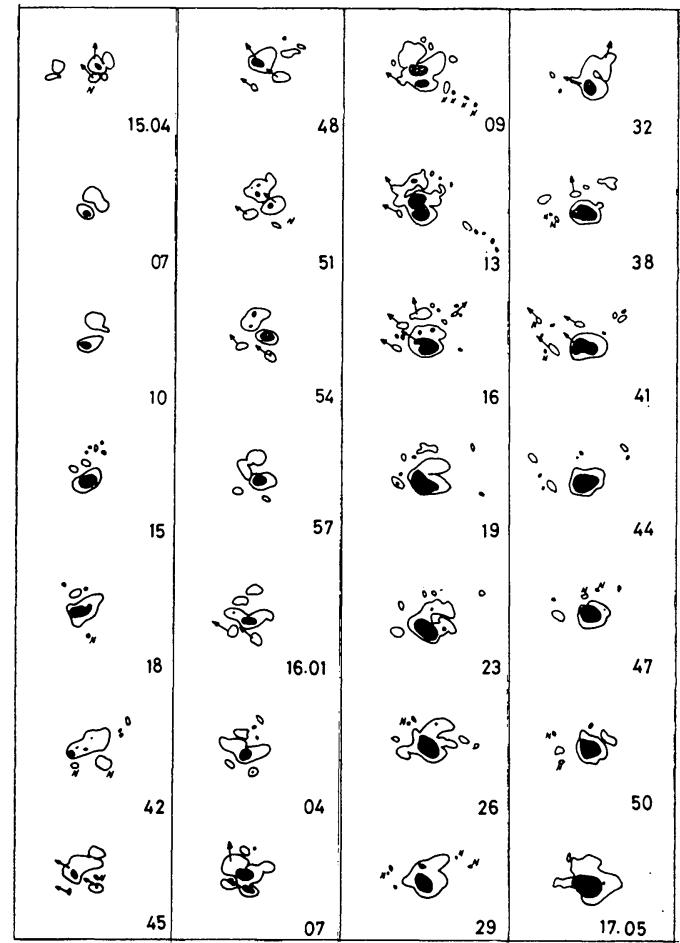

Fig. 9 Time variation of $L_{4}$ and $L_{6}$ echo patterns associated with the formation of $M_{2}$ long-lasting echo. The echo with the letter $N$ means new echo.

is found out in the cluster at 16.16 , continues to exist for a long time after that time, not showing so much variation in the shape and the size of $L_{6}$ echo. We can say that the appearance of new echoes in the cluster is remarkably different before and after the formation of the long-lasting echo. This point will be discussed in next chapter again.

\section{Structure and formation of organized pre- cipitating convective clouds}

Long-lasting echoes stated in previous chapters imply the existence of precipitating convective clouds in which the formation of precipitation as well as the supply and the release of convective energy is organized. Many authors (Newton, 1950: Browning and Ludlam, 1962; Takeda, 1972) have stated that the organized convective system has the airflow, in prevailing vertical wind shear, which is composed of an updraft in the downshear side of the system and a downdraft in the upshear side. In the system the supplies of potentially warm air at low levels and potentially cold air at middle or upper levels are maintained and the downdraft develops due to the efficient evaporation of raindrops in the latter air. The inclina- 
tion of ascending air to the upshear side would be essential for the formation and the maintenance of the system, while it is well established that most of convective clouds are inclined to the downshear side.

Here we will consider two-dimensional airflow in a vertical plane which is parallel to the moving direction of $M_{1}$ and $M_{2}$ long-lasting echoes and which cuts the echoes at their centers. Vertical profile of ambient wind in the plane, which is estimated from upper air sounding at Shionomisaki at 15.00, is shown in Fig. 10. The speed

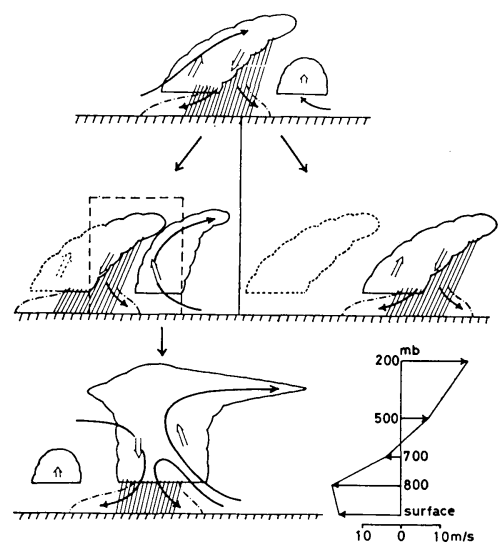

Fig. 10 Schematic representation of the transformation of cloud type from a shortlived convective cloud into an organized longlasting one.

of $M_{2}$ echo shown in Fig. 5 means that the cloud moves to WNW (to the left in the figure) with a speed slower than ambient wind at low levels. The direction of prevailing vertical shear is opposite to that of the movement of echoes.

As shown in the upper part of Fig. 10, ascending air would be inclined to the downshear side in most clouds and the downdraft would form in the downshear side of them. However, it can be inferred on the basis of the airflow stated for organized convective systems that precipitating convective clouds corresponding to $M_{1}$ and $M_{2}$ long-lasting echoes have the steady structure shown in the lowest part of Fig. 10-an updraft in the downshear side and a downdraft in the upshear side in the plane mentioned above. This assumed convective system would be maintained in the following way: potentially warm air supplied from the rear side (downshear side) of the cloud at low levels is pushed upward by the cold air diverging from the downdraft. Raindrops grown in ascending air which is inclined to the upshear side fall into potentially cold air flowing into the cloud from the fore side (upshear side) at middle levels. The downdraft is accelerated downward due to the weight of raindrops and the cooling caused by their active evaporation in potentially cold (dry) air. Strong horizontal convergence is produced in the downshear side of cold air at low levels as a result of the transport of horizontal momentum by the downdraft from middle levels into low ones. Warm and moist air flowing from the downshear side is pushed upward by strong convergence found behind the cold air and the supply of convective energy into the system can continue. Thus, once the structure shown in the lowest part of Fig. 10 forms in the convective system, it is favourable for the maintenance of the system for a long time.

In prevailing vertical wind shear, as stated by Takeda $(1965,1972)$, strong horizontal convergence can be caused in the downshear region of the downdraft at low levels. It would be possible that new convective cloud forms in the region (upper part of Fig. 10). As shown in the middle and right figure in Fig. 10, when new cloud observed in the rear of old one, which is inclined to the downshear side, develops enough to be detected by radar, old cloud would be dissipating already in most cases. In these cases newly ascending air also shows the inclination to the downshear side and the evolution of new cloud follows the same cycle as old one.

In the case of organized convective cloud, the location where new cloud forms in the downshear side is very near to that of previous updraft, so steady state seems to be realized. In this case, however, horizontal convergence at low levels can be caused in the upshear side of the downdraft too because the diverging current from the downdraft is intensive, though it is not so strong as in the downshear side. That is, we can also expect the appearance of new convective cloud in the upshear side. It was described in previous chapter that new echoes had a tendency to appear behind old ones (in their downshear side) before $M_{2}$ longlasting echo formed and they were observed in the fore side of $M_{2}$ echo (in its upshear side) after its formation. This phenomenon can be explained to reflect the change in cloud type from the short-lived cloud shown in the upper part of Fig. 10 into the organized one in the lowest part. Though we could not verify the assumption that clouds observed as long-lasting echoes have the structure of organized convective systems, the 
variation in the formation process of new clouds seems to support the assumption.

How the transformation of cloud type was made could be inferred as follows. If cold air dome moving to the left (upshear side) with the speed slower than low-level wind is kept without dissipating out due to the supply by the downdraft of old cloud for a sufficiently long time, the air pushed upward successively by cold air ascends in the arrangement inclined to the upshear side in such a way as pointed out by Newton (1967). If the process occurring on the basis of the interaction between old and new clouds remains to be at work until precipitation particles grown in new ascending air begin to fall in the upshear side of the updraft, it will be possible that the region surrounded by dashed line shown in Fig. 10 is converted into an organized convective system. The time variation of echo patterns shown in Fig. 9 can be said to indicate the change in cloud type from short-lived cloud into the organized system following the left route of Fig. 10.

Whether or not the organized system is realized through the process mentioned above would be dependent upon both the developing stages of old and new clouds and their relative locations. The fact that both $M_{1}$ and $M_{2}$ long-lasting echoes landed following nearly the same course would lead to an idea that in cases of $M_{1}$ and $M_{2}$ echoes the stages and locations of old and new clouds have not satisfied required conditions accidentally, but the dynamical or thermodynamical features of the atmosphere around the region extending from Owase Station to ESE was favourable for the formation of clouds with suitable stages and locations.

The discussion in this chapter is based on a rather two-dimensional model. As shown in Fig. 2, prevailing wind is three-dimensional. Naturally ascending and descending air currents are not confined in the plane parallel to the moving direction of $M_{2}$ echo. The area of the strong horizontal momentum from upper levels by the downdraft, is not necessarily in the plane. However, the mechanisms of the maintenance of organized convective system and the formation of new clouds would not be varied essencially by considering the influence of three-dimensional air circulation. Qualitative discussion of this chapter would be applied to real clouds treated in this paper without significant modification.

\section{Summary}

On the 14th of September in 1972 two cellular echoes having life time much longer than other ones were found out near Owase Meteorological Station among several tens of cellular echoes, though they were not different in their size and direction of movement from other echoes. The behaviors of these long-lasting cellular echoes named $M_{1}$ and $M_{2}$ and echoes surrounding them were analysed in detail using photographs of PPI radar echoes which were taken with the interval of about 3 minutes at Nagoya Meteorological Observatory.

Though $M_{1}$ echo was unable to be traced completely owing to the lack of data, it can be identified at gain level 4 for more than $60 \mathrm{~min} . M_{2}$ echo was traced for at least $90 \mathrm{~min}$ at gain level 4. Both echoes landed at the nearly same point near Owase Station. Their speed of travelling becomes slower and slower with approaching the land, and the direction remains ESE to WNE which is in good agreement with wind at $850 \mathrm{mb}$ level. They are 10 to $20 \mathrm{~km}$ in diameter as detected at gain level 4. In the case of $M_{2}$ the horizontal size of $L_{6}$ echo hardly changes with time for about one hour and the height of echo top is $8.5 \mathrm{~km}$ near Owase.

$M_{2}$ echo did not develop as an isolated one in its initial stage, but it grew to a long-lasting one in a cluster of cellular echoes which travels to WNW as a whole and which appears over the sea about $100 \mathrm{~km}$ east-south-eastward from Owase as $L_{2}$ echoes. In the cluster new echoes had a tendency to form in the back region of echoes existing previously. However, they formed in the fore region of old echoes after the formation of the long-lasting echo in the cluster.

Long-lasting cellular echoes imply the existence of precipitating convective clouds in which the formation of precipitation as well as the supply and the release of convective energy are organized. It can be inferred from the airflow in organized convective systems studied by many authors that precipitating convective clouds corresponding to long-lasting echoes have a steady structure-an updraft in the downshear side and a downdraft in the upshear side. The change in the place where new cellular echoes appear in the cluster, mentioned above, can be explained to reflect the transformation of cloud type from the short-lived cloud into the organized. It can be said that the developing stages of old and new clouds and their relative locations were favourable 
for the realization of the transformation of cloud type.

\section{Acknowledgements}

The authors wish to express their hearty thanks to staff members of Nagoya Meteorological Observatory for useful discussions and for the supply of radar photographs. This study was supported by a Fund for Scientific Research from the Ministry of Education.

\section{References}

Akiyama, T., and S. Matsumoto, 1970: The life cycle and structure of hook echoes observed in the "Baiu Front". Tenki, 17, 420-428, in Japanese.

Battan, L. J., 1953: Duration of convective radar cloud units. Bull. Amer. Met. Soc., 34, 227-228.

Browning, K. A., 1964: Airflow and precipitation trajectories within severe local storms which travel to the right of the winds. J. Atmos. Sci., 21, 634639.

, and F. H. Ludlam, 1962: Airflow in con- vective storms. Quart. J. Roy. Meteor. Soc., 88, 117-135.

Fankhauser, J. C., 1971: Thunderstorm environment interactions determined from aircraft and radar cbservations. Mon. Wea. Rev., 99, 171-192.

Newton, C. W., 1950: Structure and mechanism of the prefrontal squall line. J. Meteor., 7, 210222.

, 1967: Severe convective storms. Advances in Geophysics. Vol. 12, New York, Academic Press, 257-308.

ments of convective storms, with emphasis on size discrimination in relation to water-budget requirements. J. Appl. Meteor., 3, 651-668.

Suzuki, K., and M. Saito, 1974: Life time of convective storm cells. Kenkyu Jiho, 26, 17-29, in Japanese.

Takeda, T., 1965: The downdraft in convective shower-cloud under the vertical wind shear and its significance for the maintenance of convective system. J. Meteor. Soc. Japan, 43, 302-309.

- , 1972: Numerical simulation of a precipitating convective cloud: the formation of a "long-lasting" cloud. J. Atmos. Sci., 28, 350-376.

\title{
長続きしたセル状エコーについて
}

\author{
武田喬男・今井博雄 \\ 名古屋大学・水圈科学研究所
}

1972 年 9 月 14 日, 2 個の長続きしたセル状エコーが尾熟附近の数 10 個のセル状ェコーの中に見出された。約 3 分 毎に撮影された PPI レーダー写真をもとに，この 2 個のエコーの挙動を調べた。いずれもが殆んど同じュースをと って上陸したが，移動速度は陸に近づくにつれだんだん技とくなった。これらは初めから孤立したエコーとして生成 したものでなく，尾鶒から東南東 $100 \mathrm{~km}$ の海上に現われたセル状ェコーの群の中で形成された。このェコー群の 中で，新しいェューは古いものの後側に出来る傾向にあったが，いったん長続きするェコーが形成された後は，新 しいェコーは古いェコーの前方に見られるようになった。解析にもとづき, 組織化された対流性降水雲の形成機構を 議論する。 